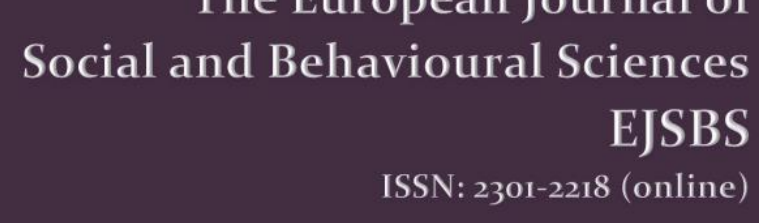

The European Journal of Social and Behavioural Sciences

EJSBS Volume II (e-ISSN: 2301-2218)

\title{
IMPROVE STUDENTS' SELF-ESTEEM THROUGH RE-LEARNING IN READING AND WRITING
}

\author{
Ann-Katrin Swärd ${ }^{\text {a* }}$ \\ ${ }^{a}$ School of Education and Communication, Jönköping University, P.O. Box 1026, SE-551 11 Jönköping, Sweden
}

\begin{abstract}
When students' fail in their reading and writing development it also affects their self-esteem and self-confidence. Too many students in Sweden fail in literacy development and therefore don't reach the goal stated in the curriculum. Their future education will not be what students had wished, instead they are more or less forced to enter an individual program at high school or quit after nine year in compulsory school. Many of these students have low self-esteem and self-confidence and their self-efficacy are also low when entering high school. The aim of this part of a longitudinal Grounded Theory-study was to conceptualize and generate a theory about what four teachers and their students in high school actually do when working with reading and writing using a specific method. The results based on qualitative research interviews, observations, questionnaires, video recording, and analysis in the tradition of grounded theory, show how teacher and students strive to increase and ensure every student in their reading and writing skills through what is labelled didactic arranging. Teachers' systematic work with reading and writing, their self-efficacy and beliefs in every student's possibilities helps students to increase their self-esteem and self-confidence.
\end{abstract}

Keywords: Grounded Theory, literacy, special education, reading instruction, self-esteem, self-confidence, self- efficacy

(C) 2012 Published by C-crcs. Peer-review under responsibility of Editor(s) or Guest Editor(s) of the EJSBS.

${ }^{*}$ Corresponding author.

E-mail address: Ann-Katrin.Sward@hlk.hj.se

doi: 10.15405/FutureAcademy/ejsbs(2301-2218).2012.2.14

This work is licensed under a Creative Commons Attribution-NonCommercial-NoDerivatives 4.0 International License. 
https://doi.org/10.15405/FutureAcademy/ejsbs(2301-2218).2012.2.14

eISSN: 2301-2218 / Corresponding Author: Ann-Katrin Swärd

Selection \& Peer-review under responsibility of the Editors

\section{Introduction}

No students ought to fail in his or her literacy acquisition. Thus, if or when they need extra support, it should be made available to them, and as early as possible. Olofsson (2002) has pointed out that problems still remain for early reading and writing acquisition. Adults who manage to avoid learning to read and write are automatically disbarred from further education (Fischbein, 1996). The starting point for this study (Swärd, 2008) using Grounded Theory was a pragmatic perspective on science and knowledge, since what was being investigated is the practical use of a specific method for teaching reading and writing. The method being investigated, the Witting method is easy to identify on a theoretical level. It is well described in a handbook, in articles and in different books that explain the ideological background as well as the development of the method. While this study is focused on the practical use of the method, there is an overlap between theoretical issues and practical considerations. A pragmatic approach to scientific endeavour highlights how people act in real situations and where those activities are possible to observe (Liedman, 1998). Dewey (1916/1997) has pointed to the strong relationship between real experience and the educational process. Schools should adapt to changes in society and teacher ought to be aware of individual differences in the students they are teaching. The practical process of teaching reading and writing may also be interpreted on the basis of Vygotskijs theories about development and mediation where proximal zones of learning and social interaction plays a big part. Current ideologies in any society also have an impact on what happens in the day-to-day environment in any school. It is within this environment teachers are responsible for organizing optimal learning experiences for every student (Vygotskij, 1934/1999). What then is required in order to be able to teach children to read and write, and to increase their self-esteem and selfconfidence and what are the important considerations when a teacher has to choose between specific didactic procedures? Research shows that individuals' with reading and writing difficulties develop other problems, like low self-image (Burden, 2005). Concept of self is 
https://doi.org/10.15405/FutureAcademy/ejsbs(2301-2218).2012.2.14

eISSN: 2301-2218 / Corresponding Author: Ann-Katrin Swärd

Selection \& Peer-review under responsibility of the Editors

broad and includes one's self- esteem, self-perception and self-image. How you perceive yourself, self-esteem develops through experiences of success or failure (Taube, 2007). Selfesteem can be disengaged from what others opinion and is a general valuation about myself in different areas like identity, appearance, properties, my role among peers. Self-esteem is built through the experiences in life but also from our life events. Self-esteem is treated in several important theories about motivation and behaviour like self-efficacy, perceived competence and explanations about success and failure. The own ability improves through support en encouragement from the surrounding and gives the courage to try in life. Self-ability is a specific concept and has central importance in general own ability and confidence to your own ability to handle stressful situations (Bandura, 1997). The difference between self-esteem and self-ability could be described, as self-ability to be about the individual's evaluation of the probability for a specific ability in a specific situation or within a specific area, will obtain a desired outcome. Self-esteem is a general evaluation about self-value (Lindwall, 2011). Due to Kåver (2009) is self-esteem as well as self-ability not a constant properties, it varies over time, in different contexts and between different situations. Self-perception is important for the individual's social and cognitive development and several studies have shown that it is related to quality of life. Our self-image is a mixture of self-esteem and self-perception (Gustafson et al, 2010).

Research results indicate that students at risk of failing in reading and writing development have more success with methods based on letter-sound connections. Successful teaching strategies should involve a balance between working with letter-sound and comprehension (Naeslund, 1956; Barr, Kamil, Mosenthal \& Pearson, 1991; Lerkkanen, 2003;). Any teaching practice includes a multitude of factors and it is almost impossible to decide whatever method might be "the best" or most effective. This study is written within the framework of special education. Special education in Sweden is based on a broad perspective. This means that difficulties or possibilities have arisen in the interaction between the 
https://doi.org/10.15405/FutureAcademy/ejsbs(2301-2218).2012.2.14

eISSN: 2301-2218 / Corresponding Author: Ann-Katrin Swärd

Selection \& Peer-review under responsibility of the Editors

environmental factors and the individual predispositions. Special education is defined as interdisciplinary and has a holistic perspective. To encourage success it is important to note that teachers' competence and their personal ethics have crucial impact on success rates. Teachers need to know and understand how students learn in different ways, that all individuals are unique and that they have different experiences and backgrounds when faced with the hurdle of learning to read and write. The challenge for teachers is to try to meet these individuals' needs and be able to tailor their teaching practice to the variation they find in their students (Chall, 1967; Fischbein, 2001; Adams, 2001, Myrberg, 2001, 2003; Nilholm \& Björck-Åkesson, 2007). Research has also shown how important an individual's self confidence is for the continuing literacy development and that reading and writing development begins quickly once children have begun school (Snow et al, 1998; Stanovich, 2000).

New research had clarified those factors that are most important for the development of reading and writing. Of most importance are teachers' competencies, engagement and positive responses to each student (Hattie, 2009). Programme for International Student Assessment (PISA) in recent years has shown that Swedish student's reading and writing skills have been declining. The students don't reach the basic level, which is important for continuing reading development (Skolverket, 2010). When student fail to reach the goal stated in the curriculum in grade 9 , the chance to enter a national program at high school is less. The opportunity students have is to apply to an individual program (ibid). Some of this individual program offers re- learning as a new option to become better in reading and writing. Relearning in this case could be defined as a new way of learning how to read and write. Early success in reading and writing is a key factor determining a student's later mental health (Barnekow \& Muijen, 2009). Successful societal development depends on the existence of a literate population (Elbro, 1999; Stanovich \& Stanovich, 1999). Research in the classroom, conducted in different contexts, could offer one way to investigate what factors could prevent 
https://doi.org/10.15405/FutureAcademy/ejsbs(2301-2218).2012.2.14

eISSN: 2301-2218 / Corresponding Author: Ann-Katrin Swärd

Selection \& Peer-review under responsibility of the Editors

failure, increase literacy and self- confidence among students. There is also a need to investigate the way skilled teachers work when teaching students how to read and write (Myrberg \& Lange, 2006).

Teacher in this study used a specific method, named Witting-method, that can be applied for students in all ages, but are most known as a re-learning method for older students and adults that earlier have failed in their reading and writing development. The Witting method (Witting, 1985, 1993, 2005) is since the 1960's a method of instruction for reading and writing at different grade-levels in Sweden and was developed by Maja Witting, education researcher and teacher training lecturer at Uppsala University, now retired. Witting developed her approach to teaching after many years of close interaction with students' learning in classroom situations. Today the method is used in different contexts. The theoretical base of the Witting method (Witting, 1985) stresses the importance of meta- cognition and linguistic awareness and is based on the idea that the learner must first master the system of relations between letters and sounds. This is a prerequisite to comprehend what is being read. The reading and writing activities can be divided into two parts. The first part is the technique is for mastering the system of relation between the letters and the sounds and is more of a mechanical part. The second part is the content, which is the creative and dynamic part of reading and writing. The Witting-method is also based on "the content neutral language structures", (ma, kli, stru) and on a dialogue between the pupil and teacher sharing responsibility for the learning process. These content neutral structures are neutral and have no meaning until the student change his or her approach from form to content and examines it in searching for content. The students have to find a word that corresponds to the specific structure. This specific method contains attentive writing, which is the technical part and working with content, the associative routine. These two components are closely connected to each other (ibid). The ethical base in this method is that every student shall success and the teacher's self-efficacy is important in this process. 
https://doi.org/10.15405/FutureAcademy/ejsbs(2301-2218).2012.2.14

eISSN: 2301-2218 / Corresponding Author: Ann-Katrin Swärd

Selection \& Peer-review under responsibility of the Editors

\section{Problem Statement}

Research (Undheim, 2009) has shown that teenagers with reading and writing difficulties had higher risks for mentally unhealthy in comparison with their peers without reading and writing difficulties. Stress and anxiety in connection to school and symptoms' of depression was also obvious. These students had to work harder to reach the grades but yet the grades didn't show the effort they had put in all schoolwork. Undheim (2003) pointed out that it was hard for many students with reading and writing difficulties, and they had to struggle on their own because of little support and understanding from their surrounding. There are a lot of studies about younger students reading and writing development but less of research for older students. More specific it is less research done in relation to teachers' way of working and assessment in the individual program at high school in Sweden with students that earlier have failed in their reading and writing (Hugo, 2007). When teacher assess students knowledge and skills they also have impact on students self- monitoring and regulation of their own learning (Earl, 2003; Hume \& Coll, 2009; Lundahl \& Folke-Fichtelius, 2010). Research by Tschannen-Moran (2011) showed that teachers sense of efficacy seemed to be most powerful related to their motivation and how they behaved in the classroom as well as how students outcome was. The teacher also tends to be more capable of working with literacy. This article will put some light over what's happen when teacher and student at one individual reading and writing program use the Witting-method in what in this method is called re-learning.

\section{Research Questions}

i. What in the Witting-method and its application has significance for students having difficulties in reading and writing?

ii. How students perceive teachers way of working?

iii. How to increase the awareness of students' literacy development? 
https://doi.org/10.15405/FutureAcademy/ejsbs(2301-2218).2012.2.14

eISSN: 2301-2218 / Corresponding Author: Ann-Katrin Swärd

Selection \& Peer-review under responsibility of the Editors

\section{Purpose of the Study}

The specific aim of the present longitudinal grounded theory study as well as this part of the study was to conceptualize and generate a theory about what two teachers and their eight students, over a number of years, actually do when working with re-learning in reading and writing using a specific method.

\section{Research Methods}

Grounded Theory, the research method in this study, has been applied from the outset of data collection and throughout the whole data-gathering procedure. Grounded Theory, an inductive method with a number of deductive steps is used to examine what skilled teachers do when working on literacy. A theory helps practitioners, in this case teacher, to understand what kinds of choices they can make in a given substantive field (Glaser \& Strauss, 1967). It is a general method that can be used with any kind of data. Grounded Theory is a qualitative method and the term "grounded" signals that the theory is grounded in empirical data (ibid). The goal of Grounded Theory is to generate and formulate hypotheses based on conceptual ideas emanating from the data that may later be subjected to normal verification procedures. Potential hypotheses are generated by constant comparison of data at different levels of abstraction. Through procedure of constant comparison and analysis of descriptive data, creation of categories, and theoretical memoing to abstract their relationships will ground understanding of the phenomenon being investigated. The goal is to 'discover' or uncover an emergent theory. Grounded Theory presupposes that this emergent theory will reflect how teachers in the substantive field deal with the main concerns of their teaching practice. (Glaser,1978, 1998, 2005). The constant comparative analytic procedure is a key constituent of the method. Even if the general idea is that transcribed text are broken into units, possible to analyse, this can be done in a variety of ways. The data at this stage are constantly compared and as the number of categories increase, they are compared, and results in more abstract 
https://doi.org/10.15405/FutureAcademy/ejsbs(2301-2218).2012.2.14

eISSN: 2301-2218 / Corresponding Author: Ann-Katrin Swärd

Selection \& Peer-review under responsibility of the Editors

categories. This abstracting continues until a central or "core category" is conceptualized and this "core category" organizes the theory (Glaser \& Strauss, 1967; Glaser, 1998).

\subsection{Participants}

The parameters of the full study are four teachers/special teachers, their 44 students, 16 girls and 28 boys in four different contexts, all using the Witting method. The four teachers were women varying in age and experience as follows: age 50, 5 years experience, age 48, 26 years of experience, age 59, 38 years experience, and age 61, 40 years experience. All subjects have been chosen through purposeful sampling, beginning with the first teacher, a strategic choice, which put the researcher in contact with the Witting method. The first teacher was also the link to the second teacher. The author met the last two teachers at a conference, randomly selecting. The age of the students ranged from 7 to 20 years and all were chosen because of their connections with the various teachers. The first context was grade 1-3 (and also 4-6, 712 years old students) and one primary teacher. The second context was grade 4-6 (9-12 years old students), third context grade 7-9 (13-16 years old students) and these contexts had the same teacher; she was a teacher in special education with. This article describes the fourth and last context, a special reading and writing program at high school, grade 1-3 (16-19 years old students). In this context the participants were two teachers (one teacher in the class and one teacher in special education) and seven students, two girls and five boys.

\subsection{Data Collection}

Data gathering was eclectic. Some lessons were video recorded. "Open questionnaires" were distributed among students in order to investigate how they expired their reading and writing process in relation to The Witting method. "Small chats" and regular interviews,

digitally recorded, with the teachers and students also contributed to the data. Also, information about what teachers and their students actually do when they are working with 
https://doi.org/10.15405/FutureAcademy/ejsbs(2301-2218).2012.2.14

eISSN: 2301-2218 / Corresponding Author: Ann-Katrin Swärd

Selection \& Peer-review under responsibility of the Editors

reading and writing was gathered through observation and note taking in the field. Data gathering and analysis followed the precepts of Grounded Theory methodology (Glaser \& Strauss, 1967; Glaser, 1978,1996,1998, 2005). Through constantly comparing, memo-writing and analysing fit into all sub-categories into to the core-category. Memo-writing is of central importance in the theoretical analysis and eventually contains hypotheses of the emergent theory. Memos, in which ideas were noting, reflections on concepts and how they related to each other, were crucial to this study, which ended in the final sorting and comparing between the four contexts that preceded the generation of the ultimate Grounded Theory (ibid). Teacher interviews, student interviews and participant observation were used in collecting the research data Interviews were semi-structured to explore issues, follow up and to allow for interaction and they were transcribed verbatim (Kvale, 1997). Observational data from participant observations, note-taking were validated through methodological triangulation, where observations, video recording, note taking, and interviews gathered the same information (Cohen, Manion, \& Morrison, 2000

\subsection{Analysis}

Grounded theory was to generate theory in a process of open, selective and theoretical coding. Open coding included line-by-line, whole-paragraph and whole-document analyses, which resulted in: naming concepts and developing categories and properties (Glaser, 1998). Concept development involved 'in-vivo', 'abstracting' and 'borrowing from the literature'. Invivo concepts, like 'students earlier experiences' or 'discuss concepts' were taken from the respondents' own words. Through abstracting and understanding from the data, situations were named like 'continued', or 'planned'. Similarities and differences within the data were identified and grouped into categories as soon as some were suitable to the same phenomena (Glaser \& Strauss, 1967). Selective coding followed after the process of open coding and each category was defined as terms of continuity, discontinuity, constrained spaces, liberated 
https://doi.org/10.15405/FutureAcademy/ejsbs(2301-2218).2012.2.14

eISSN: 2301-2218 / Corresponding Author: Ann-Katrin Swärd

Selection \& Peer-review under responsibility of the Editors

spaces, collaboration, isolation, scheduling, teamwork and competence. Through memos under the process of coding the researcher can discover theories that are relevant to the subject and therefore can be linked to the theoretical phase (Glaser, 1978). From open coding to selective coding three core categories emerged and in the last, theoretical coding they become more obvious. These core-categories were; assignment adaptation, situational adaptation and competence controlling.

\subsection{Ethical considerations}

Good (2001) shows the way to sustainable ethical thinking when doing research among people that might have some sort of learning difficulties. Factors as collaboration, consulting, respect and empowerment must be involved in what the author called emancipatory research. Due to Brodin and Renblad (2000) it is important to consider that this kind of research needs more of ethical approach since questions can awake feelings and memories from education. In the last context there were students that due to different reasons have failed in the compulsory school and perhaps felt excluded from the school. At some moment students showed feelings against video recording and no recording was done in these situations. Students, teachers and principals as well as the parents have giving their written approval for the participation in this study. Data material has been handled due to current recommendation. The persons in the study are anonymous, have been informed and knew that they could quit the participation at any time without any explanation (HSFR, 1996).

\section{Findings}

The empirical data indicated that teachers experience themselves as having to deal with complexity where they must serve both societal and individual needs. The studied teachers have struggled to ensure each student's reading and writing development and they had to do this through what is labelled 'didactic arranging'. There are many factors that teachers have to 
https://doi.org/10.15405/FutureAcademy/ejsbs(2301-2218).2012.2.14

eISSN: 2301-2218 / Corresponding Author: Ann-Katrin Swärd

Selection \& Peer-review under responsibility of the Editors

account for, including each student's personal wellbeing, their learning development and societal demands for effective teaching and successful outcomes. Teachers must meet the variation of needs and experience among students, where some have had bad experiences from elementary school. They apply their way of working with re-learning to meet the assignment stated in the curriculum. Surprisingly can students give clear information about what they think is difficult with reading and writing. However their teacher from grade nine, has less knowledge and insight when they hand over information about students earlier reading development. The earlier help and support student have received is mostly about organizational support, like being placed in a smaller group or/either special education a couple of hours every week. It is rare that the new teacher (Lena and Lisa) receive information about what students specific have worked with, the content and students reading and writing development. They talk about students as being kind and nice which they wish to help and desire to give passing grades. Sometimes they also give "kind grades" which Lisa says because the schools not want to get a bad reputation.

Teachers also says student don't want, they are not interested of learning, they are lazy and it is only hassles around students.

Lena and Lisa are well aware about students' earlier experiences and meet students by taking advantage of their interest. The first weeks are about creating satisfaction, security, and confidence and learn to know each other. It is also new experiences to talk about the feelings you have in connection to the self-image about being able to read and write. The first lesson starts with discussion with each student about their reflection about earlier reading and writing support as well as their experiences from elementary school.

Students experiences from how earlier teacher have treated them, if they have encouraged and showed that they believed in students possibilities to learn, or if they have got the feeling of being not good enough have impact in what way they believe 
https://doi.org/10.15405/FutureAcademy/ejsbs(2301-2218).2012.2.14

eISSN: 2301-2218 / Corresponding Author: Ann-Katrin Swärd

Selection \& Peer-review under responsibility of the Editors

they can learn, their self-efficacy, when they enter the individual program. (Lena, interview 1, spring-05)

Some of the students are aware about their low self-esteem and self-confidence and can talk about it while other don't like to discuss how they feel about their new situation. It is not only about to learn to read and write in a new way; re-learning. It is also to be reminded about earlier failure and some of the students have a feeling of not being clever enough:

I thought I was stupid when all the other in the class could read and I couldn't. (Lea, spring - 05)

Self-confidence has often been hurt due to earlier failure. The teachers at the beginning have to work with a lot of social aspects, since most of the students have experiences of school failure:

It might be to come in time, not to drop out on the way /.../ to be nice to each other. If you have been sitting alone in the corridor or in a very small group the experience how to collaborate and be with other peers is missing. (Lena, interview 1, spring -05)

It takes time to learn to work in another way, like listen to audio books students don't recognize. The students mostly choose books they already are familiar with and the teacher have to challenge them. In the re-learning they must learn new strategies to read and also to be aware about the problem they might have. They do attentive writing to be aware about what sounds can be troublesome for the students. One of the students said it was weird that he actually could "see" what sounds was problematic for him. For the first time he becomes metacognitive aware about what the obstacles in his reading was. To vary teaching loads and strategies and support individual needs is important at all age-levels in school and here at the individual program at high school teachers and students are well aware about that re-learning must be done. They can also explain why they didn't reach the national program they had wanted: 
https://doi.org/10.15405/FutureAcademy/ejsbs(2301-2218).2012.2.14

eISSN: 2301-2218 / Corresponding Author: Ann-Katrin Swärd

Selection \& Peer-review under responsibility of the Editors

/.../at the beginning it went well, in grade 7 it went very well. I had rather good grades and wanted to study in program for social science, I had thought but /.... (Lukas, interview 1, spring-05) Yes, it was another program I had in mind, it was some grades I didn't had and then I couldn't enter and then I came here and I'm very happy. (Laura, interview 1, spring-05)

Because the feeling student have about their ability to read and write from earlier year in school the teachers explain why it is important to come to school every day and why the schedule and their way of working with re-learning has to be in a systematic and structured way.

In the observation and video-clip it looked like the students were happy with this way of working and in the interviews they confirmed this. They felt more secured and they also felt that teachers believed in their possibility to learn. The teachers create different situations of learning and material due to the individuals need. In Witting-method no commercial material is used except from books. The use of the Witting method enables a diagnostic mode of teaching as it contains tools that allow a teacher to follow each pupil's reading and writing development and signals where early extra support may be necessary. The neutral content structures (ma, plu, stri) in the Witting method are of special prerequisite as they are triggers for the pupils' creativity vocabulary development. This in turn is important for the pupils' creation of texts and ability to achieve reading comprehension. The student's metacognitive reflection is another important factor for being successful in their reading and writing development.

When we discuss and try to find out words from these content neutral structures we also become aware about how different our vocabulary can be. We come from different villages or from the central city and dialect can be different which have impact on how we use different words. We discuss and learn from each other. (Lena and Lisa, teachers) 
https://doi.org/10.15405/FutureAcademy/ejsbs(2301-2218).2012.2.14

eISSN: 2301-2218 / Corresponding Author: Ann-Katrin Swärd

Selection \& Peer-review under responsibility of the Editors

Lena and Lisa believed their way of working was important for each student's literacy development, they showed good self-efficacy. The Witting-method has strong emphasis in collaboration and to encourage every student. This is one important factor in the method and helps students to increase their self-esteem and self-confidence. It was obvious that development occurred on all areas during the students' time in the individual program. They become safer in both verbal and written language and reading. This makes the student grow and when one student the second year met my gaze, looked at me and walked with straight back I wonder what has happened. The student seemed to have more self-confidence, which he also confirmed at the last interview in third year. He said that he had easier to talk with other and he had got the peace and time to think that he needed. (Field-notes 20050921, interview with Linus, spring-06). The students liked this way of working and thought it also was funny because they felt it was creative. Computers were used for writing and also pencil when they preferred. The important was not what sort of equipment they used; it was that they started to create their own texts. Lena and Lisa used a variation of texts both reading aloud and in audiobooks. Reading aloud was a daily activity and students were actively involved about the choice of the text. Discussion about texts could be on different level but was mostly to check if the students understand what the author had written behind the lines. Lena and Lisa are doing a renovation work, they taught student to read in a new way, re-learning. They must also work to strengthen students' self- esteem that has been broken for many years in school. Didactic arranging as individual variation is one condition to ensuring literacy. When application of Witting-method in the studied contexts the metacognitive perspective is obvious, not only in re-learning to read and write but also to increase students' self-esteem and self-confidence.

I can report more now, and it is easier to read the subtitles on TV and film. I read newspapers now and it may be easier to formulate sentences. I do not lose many letters when writing and my reading is more fluent. I still it has been good to study here and 
https://doi.org/10.15405/FutureAcademy/ejsbs(2301-2218).2012.2.14

eISSN: 2301-2218 / Corresponding Author: Ann-Katrin Swärd

Selection \& Peer-review under responsibility of the Editors

I'll recommend other to study here. I quit school tomorrow because I've got a job. (Leif,, interview 3, spring-07)

Lena and Lisa showed self-efficacy to adapt to situations, materials and time and space.

They are in charge of 'me', 'you', and 'we' - expressing this competence in documentation, by reflection and always in close collaboration with students. Ensuring literacy through didactic arranging is the proposed Grounded Theory. It derives from how the teachers work with re- learning, teaching students to read and write in a new way by using the Witting method. Experienced teachers, while showing competency in teaching reading and writing, in supporting students self-esteem and self-confidence also possess an ability to deal with all the factors involved in 'day- to- day' schoolwork. They invoke a holistic perspective that fits well into special education practice but also in general teaching practice.

\section{Conclusions}

Teachers' didactical considerations as well as their ethical values are important for how theoretical knowledge unites with teaching practice, in this case, the re-learning of reading and writing. Pragmatic, action-oriented, humanistic theories fit well with how these teachers in their didactical strategies solve their assignment of ensuring literacy. The individual and societal assignments must meld together and these teachers achieve this through their didactic arranging. The grounded theory of ensuring literacy through didactic arranging may be regarded as a model in three stages where the threads are woven together in a never- ending stream of multifactorial activities. The stages in the theory where teachers' and students' work is woven together are: assignment adaptation, situational adaptation and competence controlling. The teachers' use of the different dimensions of the Witting method reveals a common thread throughout the varying contexts. The Witting method is a structured and systematic approach that fits well with what research has shown any effective method ought to contain. The notion of ensuring literacy through didactic arranging fits well into other 
https://doi.org/10.15405/FutureAcademy/ejsbs(2301-2218).2012.2.14

eISSN: 2301-2218 / Corresponding Author: Ann-Katrin Swärd

Selection \& Peer-review under responsibility of the Editors

research about teachers support to students' literacy development (Harm, McCandliss, \& Seidenberg, 2003; Block, Gambrell, \& Pressley, 2002). Classroom collaboration between teachers and their students enables students to use meta-cognitive thinking and to reach awareness about their learning process. They are able to talk about their own learning and knowledge when they are aware about what they have learned, what they still need to learn and what they yet have not learned. They are also aware about special difficulties in their reading and writing development as well as about their self-image. A common language and shared concepts about literacy between teacher and student is needed in order to understand how students deal with their learning (Dewey, 1916/1997; Marton \& Both, 2000; Vygotskij, 1934/1999).

The importance of the grounded theory generated in this study explains how teachers handle the complexity to support both the students re-learning and their self-esteem and selfconfidence. The theory emerged from empirical data gathered in a substantive field and focusing on a specific activity, namely re-learning literacy, and can't be generalized (Glaser, 1978). Ensuring literacy through didactic arranging can contribute to new perspectives on teaching reading and writing, on teachers' competencies and also how to support students' self-esteem and increase their self-confidence. To succeed in their reading and writing and have support as early as possible is important not at least in connection to students' selfefficacy. If the students in this present study had have help much earlier in compulsory school they would have had more of self-efficacy, self-esteem and self-confidence. Their way toward high school had been different and there had been no needs for re-learning. Now they have had re-learning in an individual programme at high secondary school and their self-esteem and self-confidence have increased as long as their reading and writing skills improved. More research ought to be done about the situation for older students and their self-efficacy and selfesteem in connection to earlier failing. 
https://doi.org/10.15405/FutureAcademy/ejsbs(2301-2218).2012.2.14

eISSN: 2301-2218 / Corresponding Author: Ann-Katrin Swärd

Selection \& Peer-review under responsibility of the Editors

\section{Acknowledgements}

The authors declare that there is no conflict of interest.

\section{References}

Adams, M. J. (2001). Beginning to Read. Cambridge: England. The MIT Press.

Bandura, A. (1997). Self-efficacy. The Exercise of Control. New York: W.H. Freeman and Company.

Barnekow, V., \& Muijen, M. (2009). Child and adolescent health and development in a European perspective. International Journal of Public Health, 54, 128-130. https://doi.org/10.1007/s00038-009-5403-y

Barr, R., Kamil, M., Mosentahl, P., \& Pearson, P. D. (1991). Handbook of Reading Research. II. White Plains, NY: Longman.

Block, C. C., Gambrell, L. B., \& Pressley. M. (Eds.). (2002). Improving Comprehension Instruction. Rethinking Research Theory and Classroom Practice. Jossey-Bass.

Brodin, J., \& Renblad, K. (2000). Ethical reflections in research on persons with intellectual disabilities. Journal of Technology and Disability, 13(3), 151- 159. https://doi.org/10.3233/TAD-2000-13302

Burden, R. (2005). Dyslexia and Self concepts: Seeking a Dyslexic Identity. London: Whurr.

Chall, J. S. (1967). Learning to read: The great debate. New York: Mc Graw-Hill.

Cohen, L., Manion, L., \& Morrison, K. (2000). Research Methods in Education. London Routledge/Falmer.

Darling-Hammond, L. (1997). Doing what matters most: Investing in quality teaching. New York: National Commission on Teaching and America's Future.

Dewey, J. (1997). Demokrati och utbildning [Democracy and Education]. 
https://doi.org/10.15405/FutureAcademy/ejsbs(2301-2218).2012.2.14

eISSN: 2301-2218 / Corresponding Author: Ann-Katrin Swärd

Selection \& Peer-review under responsibility of the Editors

Earl, L. (2003). Assessment as learning: using classroom assessment to maximise student learning. Thousand Oaks, CA, Coewin Press.

Elbro, C. (1999). Dyslexia-Core Difficulties, Variability and Causes. In J. Oakhill, \& R. Beard, (Eds.), Reading development and the teaching of reading (pp. 131-151). Oxford UK: Blackwell Publishers.

Fischbein, S. (1996). Specialpedagogik och lärarutbildningen [Special Education and Teacher Education]. Pedagogisk forskning i Sverige [Educational Research in Sweden], 1(2), 89-99.

Fischbein, S. (2001). Specialpedagogisk kunskap från olika teoretiska utgångspunkter [Special Education knowledge from different theorethical starting points]. Att Undervisa [To Teach], 4, 18-19.

Glaser, B., \& Strauss, A. (1967). The discovery of Grounded Theory: strategies for qualitative research. New York: Aldine de Gruyter. https://doi.org/10.1097/00006199196807000-00014

Glaser, B (1978). Theoretical Sensitivity. Advances in the Methodology of Grounded Theory. Sociology Press.

Glaser, B. (1996). Gerund Grounded Theory: The Basic Social Process Dissertation. Sociology Press.

Glaser, B. (1998). Doing Grounded Theory: Issues and Discussion. Sociology Press.

Glaser, B. (2005). (Eds.). The Grounded Theory Review: An international journal. Sociology Press.

Good, G. A. (2001). Ethics in research with older, disabled individuals. International Journal of Rehabilitation Research, 24(3), 165-170. https://doi.org/10.1097/00004356200109000-00001

Gustavsson, J-E., Allodi, M. W., Alin-Åkerman, B., Eriksson, C., Eriksson, L., Fischbein, S., Granlund, M., Gustafsson, P., Ljungdahl, S., Ogden, T., \& Persson, R. S. ((2010). 
https://doi.org/10.15405/FutureAcademy/ejsbs(2301-2218).2012.2.14

eISSN: 2301-2218 / Corresponding Author: Ann-Katrin Swärd

Selection \& Peer-review under responsibility of the Editors

School learning and mental health: a systematic review. Stockholm: The Royal Swedish Academy of Sciences, The Health Committee.

Harm, M. W., McCandliss, B. D., \& Seidenberg, M. S. (2003). Modelling the Successes and the Failures of Interventions for Disabled Readers. Scientific Studies of Reading, 7(2), 155-182. https://doi.org/10.1207/S1532799XSSR0702_3

Hattie, J. A. C. (2009). Visible Learning: a synthesis of over 800 meta-analyses relation to achievement. New York: Routledge.

HSFR (1996). Etik. Forskningsetiska principer för humaniora och samhällsvetenskap. Humanistisk-samhällsvetenskapliga forskningsrådet [Ethics. Ethical principles for the Humanities and Social Sciences]. [Humanities and Social Sciences Research Council]. Uppsala: Produktion Ord \& Form AB.

Hugo, M. (2007). Liv och Lärande i gymnasieskolan [Life and Learning - the way towards knowledge and competence for seven underachievers at upper secondary school]. (Diss.). Jönköping University.

Hume, A., \& Coll, R. K. (2009). Assessment of learning, for learning and as learning: New Zealand case studies. Assessment in Education: Principles, Policy, and Practice, 16, 269-290. https://doi.org/10.1080/09695940903319661

Kvale, S. (1997). Den kvalitativa forskningsintervjun [The qualitative research interviews]. Lund: Studentlitteratur.

Kåver, A. (2001). Himmel och helvete och allt däremellan. Om känslor [Heaven and hell and everything there between. About feelings] Stockholm: Natur \& Kultur.

Langer, J. A. (2002). Effective literacy instruction: Building successful reading and writing programs. Urbana IL: National Council of Teachers of English.

Lerkkanen, M-K. (2003). Learning to read. Reciprocal Processes and Individual Pathways. (Diss.) Jyväskylä: Jyväskylä University, Department of Early Childhood. 
https://doi.org/10.15405/FutureAcademy/ejsbs(2301-2218).2012.2.14

eISSN: 2301-2218 / Corresponding Author: Ann-Katrin Swärd

Selection \& Peer-review under responsibility of the Editors

Liedman, S-E. (1998). Mellan det triviala och det oförutsägbara [Between the trivial and the unpredictable]. Göteborg: Daidalos

Lindwall, M. (2011). Självkänsla. Bortom populärpsykologi och enkla sanningar [Selfesteem. Beyond popular psychology and simple truths] Lund: Studentlitteratur.

Lundahl, C., \& Folke-Fichtelius, M. (ed.). (2010). Bedömning i och av skolan - praktik, principer, politik [Assessment in and out of school - practise, principle, policy] Lund: Studentlitteratur.

Marton, F., \& Both, S. (2000). Om lärande [About learning]. Lund: Studentlitteratur.

Myrberg, M. (2001). Att förebygga och möta läs- och skrivsvårigheter. En forskningsöversikt på uppdrag av Skolverket [To prevent and respond reading and writing difficulties. A research review commisioned by the National Agency for Education]. Stockholm: Skolverket.

Myrberg, M. (2003). Att skapa konsensus om skolans insatser för att motverka läs- och skrivsvårigheter [A consensus on the school's efforts to combat reading and writing difficulties]. Stockholm: Skolverket.

Myrberg, M., \& Lange, A. (2006). Identifiering, diagnostik samt specialpedagogiska insatser för elever med läs-och skrivsvårigheter. Konsensusprojektet [Identification, diagnosis, and special education efforts for students with reading and writing difficulties]. Stockholm: Specialpedagogiska Institutet och Lärarhögskolan, Stockholm.

Naeslund, J. (1956). Metodiken vid den första läsundervisningen [Methodology at the first reading instruction]. (Diss.) Uppsala: Almquist \& Wiksells.

Nilholm, C., \& Björck-Åkesson, E. (Eds.). (2007). Reflektioner kring specialpedagogik - sex professorer om forskningsområdet och forskningsfronterna. Vetenskapsrådets Rapportserie 5, Stockholm: Vetenskapsrådet. [Reflections on special education - six professors reflections on research and research fronts]. National Research Council. Report 5. 
https://doi.org/10.15405/FutureAcademy/ejsbs(2301-2218).2012.2.14

eISSN: 2301-2218 / Corresponding Author: Ann-Katrin Swärd

Selection \& Peer-review under responsibility of the Editors

Skolverket. (2010). PISA 2009. 15-åringars läsförståelse och kunskap i matematik och naturvetenskap [15-years reading comprehension and knowledge in mathematics and science]. Rapport 352.

Snow, C. E., Burns, S., \& Griffin, P. (Ed.). (1998). Preventing Reading Difficulties in Young Children. Washington DC: National Academy Press.

Stanovich, K. E. (1986). Matthew effects in reading: Some consequences of individual differences in the acquisition of literacy. Reading Research Quarterly, 21, 360-407.

Stanovich, K., \& Stanovich, P. (1999). How Research Might Inform the Debate about Early Reading Acquisition. In Oakhill, \& R. Beard, (Eds.), Reading Development and the Teaching of Reading (pp. 13-31). Cambridge: UK.

Swärd, A-K. (2008). Att säkerställa skriftspråklighet genom medveten arrangering. Wittingmetoden tillämpning i några olika lärandemiljöer [Ensuring Literacy through Didactic Arranging. The Witting method set in context]. (Doctoral Dissertation) Stockholms University.

Taube, K. (2007). Läsinlärning och självförtroende - psykologiska teorier, empiriska undersökningar och pedagogiska konsekvenser [Literacy learning and self-confidence - psychological aspects, empirical studies and didactic consequences] Stockholm: Nordstedts Akademiska förlag.

Tschannen-Moran, D. J. (2011). Exploring literacy teachers' self-efficacy believes: Potential sources at play. Teaching and Teacher Education, 27, 751-761. https://doi.org/10.1016/j.tate.2010.12.005

Undheim, A. M. (2003). Dyslexia and psychosocial factors. A follow-up study of young Norwegian adults with a history of dyslexia in childhood. Nordic Journal of Psychiatry, 57, 221-226. https://doi.org/10.1080/08039480310001391 
https://doi.org/10.15405/FutureAcademy/ejsbs(2301-2218).2012.2.14

eISSN: 2301-2218 / Corresponding Author: Ann-Katrin Swärd

Selection \& Peer-review under responsibility of the Editors

Undheim, A. M. (2009). A Thirteen-year - follow-up study of Young Norwegian Adults with Dyslexia in Childhhod: Reading Development and Educational Levels. Dyslexia, 15, 291-303. https://doi.org/10.1002/dys.384

Vygotskij, L. S. (1999). Tänkande och språk. (Original Edition 1934, Thought and Language) Göteborg: Daidalos.

Witting, M. (1985). Metod för läs- och skrivinlärning [Method to read and write]. Solna: Ekelunds förlag.

Witting, M. (1986). Handledning [Supervision]. Solna: Ekelunds förlag.

Witting. M. (1993). Wittingmetoden - en metod för många. Ominlärning - ett sätt att övervinna läs- och skrivsvårigheter [Witting method - a method for many. Re-learning - a way to overcome reading and writing difficulties]. Solna: Ekelunds förlag.

Witting, M. (2005). Wittingmetodens idébakgrund [The idea background of the Witting method]. Solna: Ekelunds Förlag. 